Abbreviated Key Title: Sch J Econ Bus Manag

ISSN 2348-8875 (Print) | ISSN 2348-5302 (Online)

Journal homepage: https://saspublishers.com/sjebm/

\title{
The Socio-Economic and Other Living Conditions of Slum Dwellers: A Study

\author{
M. Kulasekhar ${ }^{1 *}$, Prof. K. Dasaratharamaiah ${ }^{2}$
}

${ }^{1}$ Ph.D. Scholar, Dept. of Economics, Sri Krishnadevaraya University, Ananthapuramu, A.P. 515003 Andhra Pradesh India

${ }^{2}$ Professor, Dept. of Economics and Applied Economics, Sri Krishnadevaraya University, Ananthapuramu, A.P 515 003asa Andhra Pradesh India

The number of urban dwellers in India accounted for about $10 \%$ of the urban population of the world and about $21 \%$ of Asia population. The level of urbanization increased from $10.30 \%$ in 1911 to $31.16 \%$ in 2011 . The percentages of slum dwellers are more (12.04\%) in Andhra Pradesh and low (1.12\%) in Arunachal Pradesh. Out of 100 sample respondent slum dwellers in four slum areas, $44 \%$ are Hindus, 30\% are Muslims, $22 \%$ are Christians and $4 \%$ belongs to other religion like Jains, Buddhist etc., As the slum population are not originally natives of local area, mainly migrated from different parts of the state and country and so that mixed religion and cast people are staying in the slums. The slum dwellers are mainly migrated from different places to urban India in search of getting some employment to earn money to meet their family expenditure and other living purpose. $22 \%$ of slum dwellers were migrated from rural to urban areas, due to debt burden. $37 \%$ of slum dwellers were migrated in search of employment, $21 \%$ migrated for their children's education purpose, $16 \%$ of slum people migrated to do some business in urban area It reveals that $58 \%$ of slum dwellers are getting water from public taps in their slums, $26 \%$ of the respondent slum dwellers have Municipal tap connection for their dwellings and about $16 \%$ are purchasing mineral water for drinking purpose. The living conditions of slum dwellers are poor with their inadequate income and employment. The housing conditions of slum dwellers are poor. It is necessary to provide proper infrastructural facilities in the slum areas. Internal roads, drainage system to be improved. Creating awareness on maintaining health and avoiding alcohol and tobacco consumption among slum dwellers is necessary.

Keywords: Slum Area, Slum Dwellers, Migration, Urban Population, Living Conditions, Education, Employment. Copyright @ 2020: This is an open-access article distributed under the terms of the Creative Commons Attribution license which permits unrestricted use, distribution, and reproduction in any medium for non-commercial use (NonCommercial, or CC-BY-NC) provided the original author and source are credited.

\section{INTRODUCTION}

The slums have been a part of the history of utmost all cities/towns, particularly during the phase of urbanization and industrialization. Slums are a type of settlement affordable and accessible to poor in cities. The slums are often overcrowded with many people crammed into very small living spaces. According to 2011 census of India, urban population of the country stood at 377.10 million which is $31.16 \%$ of the total population. It may be expected that India's urban population is likely to be doubled by 2030 by reaching 600 million. The sprouting of slums in the urban areas is the direct outcome of greater economic opportunities available in the cities/towns.

The migration of people from rural to urban areas and natural increase in the number of inhabitants have led to rapid population growth in the cities/towns. The unskilled rural-urban migrants are joining in low productivity informal sector which generate meagre earnings and with the high cost of living in the urban areas forced them to settle down in low lying areas with ramshackle dwellings Thus, due to pressure on Urban areas, the governments are unable to provide basic necessities such as housing, safe drinking water, sanitation, internal roads and access to proper health care services. This is true in case of slum dwellers who are the worst sufferers.

\section{Urban Population and Levels of Urbanisation}

The global urban population has exceeded the global rural population. The number of urban dwellers increased from 220 million in 1900 to 732 million in 1950 and is estimated to reach 3.9 billion. The number of urban dwellers reached 3 billion in 2003 and is projected to increase to 4 billion in 2018 and 5 billion by 2030 . As per 2011 census of India, there are 7935 urban Agglomeration /towns in India comprising 4011 statutory towns and 3894 census towns with a population of about 377 million representing $3 \%$ of India's population of 1210 million. The number of 
urban dwellers in India accounted for about $10 \%$ of the urban population of the world and about $21 \%$ of Asia population. The level of urbanization increased from $10.30 \%$ in 1911 to $31.16 \%$ in 2011.

The total population of India over a period of time increased from 238.40 million in 1901 to 1210.50 million by 2011 as shown in table 1 . The number of urban agglomerations /towns was 1917 in India in 1901 and increased to 3059. From 1951 to 2011 the number of towns again increased to 7933. The urban population increased from 25.80 million i.e., $10.80 \%$ of total population to 377.10 million with $31.20 \%$ of total population of the country.

Table-1: Urban Population and Levels of Urbanisation in India (1901-2011)

\begin{tabular}{|l|l|l|l|l|}
\hline Year & $\begin{array}{c}\text { Total Population } \\
\text { (in Millions) }\end{array}$ & No. of UAs/Towns & $\begin{array}{c}\text { Urban Population } \\
\text { (in Millions) }\end{array}$ & $\begin{array}{c}\text { \% of Urban } \\
\text { Population }\end{array}$ \\
\hline 1901 & 238.40 & 1917 & 25.80 & 10.80 \\
\hline 1911 & 252.10 & 1909 & 25.90 & 10.30 \\
\hline 1921 & 251.30 & 2047 & 28.10 & 11.20 \\
\hline 1931 & 278.90 & 2219 & 33.40 & 12.00 \\
\hline 1941 & 318.60 & 2424 & 44.10 & 13.90 \\
\hline 1951 & 361.10 & 3059 & 62.40 & 17.30 \\
\hline 1961 & 439.20 & 2699 & 78.90 & 18.00 \\
\hline 1971 & 548.20 & 3126 & 109.10 & 19.90 \\
\hline 1981 & 683.30 & 3949 & 159.50 & 23.30 \\
\hline 1991 & 846.30 & 4615 & 217.60 & 25.70 \\
\hline 2001 & 1028.60 & 5161 & 286.10 & 27.80 \\
\hline 2011 & 1210.50 & 7933 & 377.10 & 31.20 \\
\hline
\end{tabular}

Source: Census Data, 2011

\section{Slum Dwellers in India}

A heavy populated urban area characterized by substandard housing and squalor grow up in a slum near downtown lived in the slums by river belt or drain belt or in a low level water flowing areas with congested roads and drains. The $21^{\text {st }}$ century has witnessed a rapid growth of urban population coupled with incommensurate development of social facilities which has resulted in the creation of slums associated problems of an alarming magnitude owing to lack of employment and suitable jobs in the country side, people from rural areas migrate to the towns/cities. In cities, they obtain jobs but their income hardly allows them to have good accommodation or neighborhood. Hence, they occupy vacant land or try to adjust themselves in the existing slums. This results into a growth of slums and slum dwellers.

The percentage of urban population to total population is high in Delhi with $97.50 \%$ followed by $97.25 \%$ in Chandigarh (Table 2). In the States of India it varied between $10.03 \%$ in Himachal Pradesh to $52.11 \%$ in Mizoram. The percentage of slum dwellers are more in $12.04 \%$ in combined Andhra Pradesh and low in $1.12 \%$ Arunachal Pradesh. The literacy rate of total population is high $(98.11 \%)$ in Mizoram followed by Kerala and low in Chandigarh (66.38\%). The literacy rate among slum population is high ((88.78\%) in Mizoram followed by Meghalaya $(88.10 \%)$ and low in Chandigarh (52.10\%)

\section{Reasons for increased Slum Population in India}

The general reasons for the increase of slum dwellers are due to industrialisation in urban areas, migration from rural to urban, lack of employment opportunities in the rural areas of India where agriculture is the basic industry to provide seasonal employment that too which depends on rainfall and other natural conditions. The low wages and inadequate infrastructural facilities for living of the migrant people in urban India is also one the cause. Industrialization has been increased in the country and large as well as medium-sized industries have been established in several parts of the country. The industrial concerns have attracted the rural masses for employment. The uneconomic subdivision of holdings from generation to generation and unprofitable agriculture which suffering from periodic famines, floods, pestilences and other calamities have aggravated the problem of increase of slum population.

Most of towns/cities are congested and overcrowded with the lack of civil amenities when people thrown into the cities to work in industries, in construction work, in transport and trading Corporations and they fail to find housing accommodation. If there were thousands of industrial workers without residential facilities they try to make some temporary arrangements near the place of their work. Whenever they find vacant Government land, large number of unhygienic huts spring up near the factories or commercial concerns. These naturally turn into slums because the area is small, proper roads are not available, facilities like electricity; water and toilet do not exist. The large number of urban workers is unskilled labourers earning low wages. Many of them are employed on temporary basis. They cannot afford to have cement-mortar houses with proper facilities. So, they are forced to live in slums. 
M. Kulasekhar \& K. Dasaratharamaiah., Sch J Econ Bus Manag, April, 2020; 7(4): 147-158

Table-2: State Wise Literacy Levels of Slum Dwellers in India (2011 Census)

\begin{tabular}{|c|c|c|c|c|c|c|}
\hline S.No. & State/UT & $\begin{array}{c}\text { Total } \\
\text { Population }\end{array}$ & $\begin{array}{c}\text { Percentage } \\
\text { of Urban } \\
\text { Population }\end{array}$ & $\begin{array}{c}\text { Percentage } \\
\text { of Slum } \\
\text { Dwellers }\end{array}$ & $\begin{array}{c}\text { Literacy } \\
\text { level of Total } \\
\text { Population }\end{array}$ & $\begin{array}{c}\text { Literacy Level } \\
\text { of Slum } \\
\text { Dwellers }\end{array}$ \\
\hline 1. & A\&N Islands & 380581 & 37.70 & 3.72 & 82.80 & 76.35 \\
\hline 2. & Andhra Pradesh & 84580777 & 34.18 & 12.04 & 75.32 & 68.90 \\
\hline 3. & Arunachal Pradesh & 1383727 & 22.94 & 1.12 & 69.39 & 62.17 \\
\hline 4. & Assam & 31205576 & 14.10 & 0.63 & 81.57 & 74.55 \\
\hline 5. & Bihar & 104099452 & 11.29 & 1.19 & 68.15 & 56.70 \\
\hline 6. & Chandigarh & 1055450 & 97.25 & 9.01 & 66.38 & 52.20 \\
\hline 7. & Chhattisgarh & 25545198 & 23.24 & 7.43 & 80.36 & 74.20 \\
\hline 8. & Delhi & 16787941 & 97.50 & 10.63 & 75.16 & 65.60 \\
\hline 9. & Goa & 1458545 & 62.17 & 1.80 & 82.44 & 60.85 \\
\hline 10. & Gujarat & 60439692 & 42.60 & 2.78 & 70.49 & 64.25 \\
\hline 11. & Haryana & 25351462 & 34.88 & 6.56 & 75.87 & 71.50 \\
\hline 12. & Himachal Pradesh & 6864602 & 10.03 & 0.89 & 87.74 & 82.25 \\
\hline 13. & Jammu\& Kashmir & 12267032 & 26.11 & 5.28 & 68.02 & 66.90 \\
\hline 14. & Jharkhand & 32988134 & 24.05 & 1.13 & 75.51 & 71.65 \\
\hline 15. & Karnataka & 61095297 & 38.67 & 5.39 & 75.63 & 67.25 \\
\hline 16. & Kerala & 33406061 & 47.70 & 0.60 & 93.11 & 84.75 \\
\hline 17. & Madhya Pradesh & 72626809 & 27.63 & 7.83 & 77.25 & 73.25 \\
\hline 18. & Maharashtra & 112374333 & 45.22 & 10.54 & 84.55 & 79.35 \\
\hline 19. & Meghalaya & 2966889 & 20.07 & 1.94 & 89.02 & 88.10 \\
\hline 20. & Mizoram & 1097206 & 52.11 & 7.16 & 98.11 & 88.78 \\
\hline 21. & Nagaland & 1978502 & 28.86 & 4.16 & 88.85 & 80.32 \\
\hline 22. & Odisha & 41974218 & 16.69 & 3.72 & 78.95 & 70.00 \\
\hline 23. & Puducherry & 1247953 & 68.33 & 11.58 & 81.39 & 74.25 \\
\hline 24. & Punjab & 27743338 & 37.48 & 5.26 & 74.18 & 71.20 \\
\hline 25. & Rajasthan & 68548437 & 24.87 & 3.02 & 69.79 & 63.50 \\
\hline 26. & Tamil Nadu & 72147030 & 48.40 & 8.04 & 82.06 & 76.70 \\
\hline 27. & Tripura & 3673917 & 26.17 & 3.80 & 90.71 & 86.50 \\
\hline 28. & Uttar Pradesh & 199812341 & 22.27 & 3.12 & 68.98 & 62.50 \\
\hline 29. & Uttarakhand & 10086292 & 30.23 & 4.84 & 76.88 & 66.70 \\
\hline \multirow[t]{2}{*}{30.} & West Bengal & 91276115 & 31.87 & 7.03 & 81.38 & 74.05 \\
\hline & India & 1210854977 & 31.16 & 5.41 & 77.72 & 71.65 \\
\hline
\end{tabular}

Source: Census data 2011

\section{REVIEW OF LITERATURE}

Siddhartha Agarwal and Shivani Taneja [1] stated that increasing urbanization has resulted in a faster growth of slum population. $\mathrm{He}$ found that disparities among slums exist owing to various factors and led to varying degrees of health burden on the slum children. In view of the differential vulnerabilities across slums, an urban child health program should built context appropriate and community-needresponsive approaches to improve children's health in the slums.

According to Ratan Khasnabis and Tania Chatterjee India is yet to achieve the goal of universalization of elementary education or $100 \%$ enrolment and retention of children with schooling facilities in all habitations. The author examined various reasons for poor attendance behavior of students in formal schools. Sunny Jose and Navaneetham [2] observed that whether access to aspects of social infrastructure, such as toilet facilities, drinking water in the premises and clean cooking fuels leads to a decline in the incidence of undernutrition among slum dwellers.

Goswami and Manna [3] noticed that the appearance of slums may be seen as a byproduct in the process of urbanization in a developing country like India. The urban areas are part of the fundamental changes in the society leading to socio-economic development and modernization. Samarrai $S$ and Peasgood T [4] identified that children's educational attainment has mainly been associated with parental education levels and with the household socioeconomic profile. Akter $\mathrm{T}$ [5] focused the socioeconomic conditions of slum dwellers and their consumption patterns. The study analysed the living conditions, physical environment, and household's health behavior of slum dwellers in Dhaka City.

Inter and intra migration and the socioeconomic strata of the slum dwellers of Gandhinagar slum is pointed by Ali AM and Toran K [6]. The study found that majority of the migrants has come to this 
particular area, because of cheap accommodation. The study of Madhusoodhanan V [7] examined the problems of slum dwellers and various governmental measures implemented for their rehabilitation. The study observed that both the pull and push factors were influenced for the growth of slums. In the light of the above studies to fulfil the gaps, a study has been conducted on the socio-economic and other living conditions of slum dwellers in Ananthapuramu Municipal Corporation of Andhra Pradesh.

\section{OBJECTIVES OF THE STUDY}

- To examine the urbanization and increased slum population in Indian cities/towns

- To analyse the socio-economic conditions of slum dwellers in the study area

- To assess the dwelling conditions of slum people under study

- To know the educational standards of slum dwellers

- To describe the general living conditions of slum dwellers in the study area

- To suggest possible measures to improve the living conditions of slum dwellers

\section{METHODOLOGY OF THE STUDY}

For the purpose of the study, the district headquarters town of Ananthapuramu in Rayalaseema region of Andhra Pradesh has been purposively selected. There are 50 Municipal divisions and 64 slums in the town. From among 61 slums, 4 slums namely (1) Rani Nagar (S1), Munna Nagar (S2) (3) Hanuman Colony (S3) and (4) Maruthi Nagar Railway Track (S4) are selected for the study. From each slum 25 slum dwellers from different social category were selected for the study. This altogether covers 100 sample slum dwellers from Ananthapuramu Municipal Corporation. In the following lines, the names of slums can be read simply as S1, S2, S3, and S4.

\section{Urban Poor of Ananthapuramu Municipal Corporation}

Out of the total population of 2, 63,898 of Ananthapuramu town, 74,964 are living in notified and non-notified slum and poor areas. Majority of them leading their life as daily wage labourers, under employed labourers, seasonal labourers etc. At present there are 64 slum and poor settlements in the town, out of which 43 are notified and 21 are non-notified slums. The condition of living environment like roads, drainage facilities, housing, electricity, basic education, health are not at satisfactory level and definitely needs improvement for better health and hygienic conditions of slum poor.

\section{RESULTS AND DISCUSSIONS}

Based on the field survey data, the socioeconomic and other living conditions of slum dwellers in Ananthapuramu Municipal Corporation of Rayalaseema region in Andhra Pradesh has been discussed in the following pages.

\section{Age of the Slum Dwellers}

In an empirical study, the sample households play an important role in assessment of their knowledge towards education, employment, social awareness and other living conditions of their community. In this regard, the age of the respondent slum dwellers was categorised in to four categories such as less than 25 years, $26-40$ years, $41-60$ years and above 60 years. The respondent slum dwellers interviewed in Rani Nagar slum (S1), $16 \%$ belongs to less than 25 years of age, $32 \%$ in the age group of $26-40$ years, $28 \%$ belongs to OC category and 24\% belongs to 41-60 years of age. In Munna Nagar slum (S2) area, $36 \%$ are in the age group of 41 to 60 years, 245 are between 26 and 40 years and $20 \%$ each in the age group of less than 25 years and more than 60 years (Table 3 ).

In hanuman colony slum (S3) area, only $8 \%$ of respondent slum dwellers are in the age group of less than 25 years, $40 \%$ are in the age group of 41-60 years of age, $28 \%$ fall under the age group of 26-40 years and remaining $24 \%$ are above 60 years of age. Regarding Maruthi Nagar Railway Track Slum (S4) area, 24\% under less than 25 years of age, $32 \%$ are between 26 and 40 years of age, $16 \%$ fall in the group of 41-60 years and $28 \%$ of the respondent slum dwellers are in the age group of above 60 years. Out of 100 sample respondents, $17 \%$ are in the age group of less than 25 years, $29 \%$ each are in the age group of 26-40 years and 41-60 years and remaining $25 \%$ are above 60 years of age.

Table-3: Ag e of Respondent Slum Dwellers

\begin{tabular}{|c|c|c|c|c|c|}
\hline Slum/Age & < 25 Years & 26-40 Years & 41-60 Years & > 60 Years & Total \\
\hline S1 & $04(16)$ & $08(32)$ & $06(24)$ & $07(28)$ & $25(100)$ \\
\hline S2 & $05(20)$ & $06(24)$ & $09(36)$ & $05(20)$ & $25(100$ \\
\hline S3 & $02(08)$ & $07(28)$ & $10(40)$ & $06(24)$ & $25(100)$ \\
\hline S4 & $06(24)$ & $08(32)$ & $04916)$ & $07(28)$ & $25(100)$ \\
\hline Total & $17(17)$ & $29(29)$ & $29(29)$ & $25(25)$ & $100(100)$ \\
\hline
\end{tabular}

Source: Field Survey Data, Note: Figures in Parentheses Indicates Percentages to their Total 


\section{Religion of the Slum Dwellers}

Out of 100 sample respondent slum dwellers in four slum areas, $44 \%$ are Hindus, $30 \%$ are Muslims, $22 \%$ are Christians and $4 \%$ belongs to other religion like Jains, Buddhist etc., as the slum population are not originally natives of local area, mainly migrated from different parts of the state and country and so that mixed religion and cast people are staying in the slums (Table 4). In S1 slum area, $40 \%$ are Hindus, $20 \%$ are
Muslims and $32 \%$ are Christians and $8 \%$ are from other religions who migrated from other states like Rajasthan, Bihar etc., in S2 slum area, $36 \%$ are Hindus $44 \%$ are Muslims, and $20 \%$ are Christians. It reveals that in S3 slum, $48 \%$ are Hindus, $32 \%$ are Muslims, $16 \%$ are Christians and $4 \%$ are other. As shown in the table 4, $52 \%$ of Hindus, $24 \%$ of Muslims, $20 \%$ of Christians and $4 \%$ of other religions are the respondent slum dwellers in $\mathrm{S} 4$ slum area.

Table-4: Religion of Respondent Slum Dwellers

\begin{tabular}{|c|c|c|c|c|c|}
\hline Slum & Hindu & Muslim & Christian & Others & Total \\
\hline S1 & $10(40)$ & $05(20)$ & $08(32)$ & $02(08)$ & $25(100)$ \\
\hline S2 & $09(36)$ & $11(44)$ & $05(20)$ & $00(00)$ & $25(100$ \\
\hline S3 & $12(48)$ & $08(32)$ & $04(16)$ & $01(04)$ & $25(100)$ \\
\hline S4 & $13(52)$ & $06(24)$ & $05(20)$ & $01(04)$ & $25(100)$ \\
\hline Total & $44(44)$ & $30(30)$ & $22(22)$ & $04(04)$ & $100(100)$ \\
\hline
\end{tabular}

Source: Field Survey Data, Note: Figures in Parentheses Indicates Percentages to their Total

\section{Sex-Wise Distribution of Respondent Slum Dwellers}

As shown in table 5, in S1 slum, $76 \%$ are male and $24 \%$ are female respondent slum dwellers. In S2 slum area, $56 \%$ of the respondent dwellers are male and remaining $44 \%$ are female. Out of 25 respondent slum dweller households in S3 slum area, $72 \%$ are male and $28 \%$ are female. It may also notice that $6 \%$ of male and $32 \%$ of female respondent slum dwellers are identified in S4 slum under study. Out of the total slum dwellers under study, $68 \%$ are male and $32 \%$ are female.

Table-5: Sex-Wise Distribution of Respondent Slum Dwellers

\begin{tabular}{|c|c|c|c|}
\hline Slum & Male & Female & Total \\
\hline S1 & $19(76)$ & $06(24)$ & $25(100)$ \\
\hline S2 & $14(56)$ & $11(44)$ & $25(100$ \\
\hline S3 & $18(72)$ & $07(28)$ & $25(100)$ \\
\hline S4 & $17(68)$ & $08(32)$ & $25(100)$ \\
\hline Total & $68(68)$ & $32(32)$ & $100(100)$ \\
\hline
\end{tabular}

Source: Field Survey Data, Note: Figures in Parentheses Indicates Percentages to their Total

\section{Marital Status of Slum Dwellers}

The marital status of slum dwellers under study is presented in table 6 and it reveals that out of total respondent slum dwellers, $70 \%$ are married, $12 \%$ are unmarried, $10 \%$ are widowed and remaining $8 \%$ are divorced or single living respondent households. It may be noticed that in S1 slum area, $68 \%$ are married, $16 \%$ are unmarried, $12 \%$ are widowed and only $4 \%$ are divorced/single. In S2 slum, $68 \%$ are married, $12 \%$ are unmarried, $8 \%$ are divorced and another $12 \%$ belongs to divorced/single living. In S3 slum, $68 \%$ are married, $12 \%$ each are unmarried and divorced respectively and $8 \%$ are widowed. Out of 25 respondent slum dwellers in $\mathrm{S} 4$ slum, $72 \%$ are married, $12 \%$ each are unmarried and widowed and only one respondent slum dweller is divorced.

Table-6: Marital Status of Respondent Slum Dwellers

\begin{tabular}{|c|c|c|c|c|c|}
\hline Slum & Married & Unmarried & Widowed & Divorced/Single & Total \\
\hline S1 & $17(68)$ & $04(16)$ & $03(12)$ & $01(04)$ & $25(100)$ \\
\hline S2 & $18(72)$ & $02(08)$ & $02(08)$ & $03(12)$ & $25(100$ \\
\hline S3 & $17(68)$ & $03(12)$ & $02(08)$ & $03(12)$ & $25(100)$ \\
\hline S4 & $18(72)$ & $03(12)$ & $03(12)$ & $01(04)$ & $25(100)$ \\
\hline Total & $70(70)$ & $12(12)$ & $10(10)$ & $08(08)$ & $100(100)$ \\
\hline
\end{tabular}

Source: Field Survey Data, Note: Figures in Parentheses Indicates Percentages to their Total

\section{Age at Marriage of Slum Dwellers}

It reveals that $49 \%$ of sample slum dwellers were married at the age of less than 18 years. $31 \%$ were married at the age of 18-21 years, $15 \%$ married at 21-25 years of age and only $5 \%$ were married at the age of above 25 years. It shows that majority of the slum dwellers are getting married at their early age. As shown in table $7,48 \%$ in $\mathrm{S} 1,52 \%$ in $\mathrm{S} 2,40 \%$ in $\mathrm{S} 3$ and
$56 \%$ in S4 slum were married less than 18 years of age. Another $24 \%$ in $\mathrm{S} 1,32 \%$ in $\mathrm{S} 2,36 \%$ in S3 and again $32 \%$ in $\mathrm{S} 4$ slum area were married between 18 and 21 years. It may also noticed that $20 \%$ in S1, $12 \%$ each in $\mathrm{S} 2$ and $\mathrm{S} 4$ slums and $16 \%$ in S3 slum area were married between 21-25 years of age. It reveals that $8 \%$ each in $\mathrm{S} 1$ and $\mathrm{S} 3$ slum areas, and $4 \%$ in S2 slum area, the slum dwellers were married at the age of above 25 years. 
Table 7: Age at Marriage of Respondent Slum Dwellers

\begin{tabular}{|c|c|c|c|c|c|}
\hline Slum/Age & < 18 Years & $\mathbf{1 8 - 2 1}$ Years & 21-25 Years & >25 Years & Total \\
\hline S1 & $12(48)$ & $06(24)$ & $05(20)$ & $02(08)$ & $25(100)$ \\
\hline S2 & $13(52)$ & $08(32)$ & $03(12)$ & $01(04)$ & $25(100$ \\
\hline S3 & $10(40)$ & $09(36)$ & $04(16)$ & $02(08)$ & $25(100)$ \\
\hline S4 & $14(56)$ & $08(32)$ & $03(12)$ & $00(00)$ & $25(100)$ \\
\hline Total & $49(49)$ & $31(31)$ & $15(15)$ & $05(05)$ & $100(100)$ \\
\hline
\end{tabular}

Source: Field Survey Data, Note: Figures in Parentheses Indicates Percentages to their Total

\section{Educational Status of Slum Dwellers}

The health, education and social welfare assume greater importance in programs of slum improvement than housing and other public services. Of them education is the foremost single factor responsible in the economic development of slum dwellers. The educational level of slum dwellers is very low in India and there is a need to improve the educational levels of slum dwellers. Table 8 reveals that $28 \%$ of slum dwellers in S1 slum and S4 slum, 32\% in S2 slum and $24 \%$ of slum people in S3 slum area are illiterates. It shows that $24 \%$ in $\mathrm{S} 1$ slum, $32 \%$ in $\mathrm{S} 2$ slum, $28 \%$ in $\mathrm{S} 3$ slum and $20 \%$ in S4 slum have an educational level of up to primary level. It may noticed that $20 \%$ each in S1 and S2 slums, $16 \%$ in S3 and $32 \%$ of slum dwellers in S4 slum are studied up to Upper Primary ( $7^{\text {th }}$ Class) level. The secondary level educational standards are $12 \%$ in $\mathrm{S} 1,8 \%$ in $\mathrm{S} 2,20 \%$ in $\mathrm{S} 3$ and $16 \%$ in $\mathrm{S} 4$ slum area. It shows that $8 \%$ each in $\mathrm{S} 1$ and $\mathrm{S} 2$ slums, $4 \%$ each in S3 and S4 slums were studied up to intermediate and only $8 \%$ in S1 and S3 slum areas were studied up to degree level education under study.

Table-8: Educational Status of Respondent Slum Dwellers

\begin{tabular}{|c|c|c|c|c|c|c|c|}
\hline Slum & Illiterate & Primary & $\begin{array}{c}\text { Upper } \\
\text { Primary }\end{array}$ & Secondary & Intermediate & $\begin{array}{c}\text { Degree\& } \\
\text { Above }\end{array}$ & Total \\
\hline S1 & $07(28)$ & $06(24)$ & $05(20)$ & $03(12)$ & $02(08)$ & $02(08)$ & $25(100)$ \\
\hline S2 & $08(32)$ & $08(32)$ & $05(20)$ & $02(08)$ & $02(08)$ & $00(00)$ & $25(100$ \\
\hline S3 & $06(24)$ & $07(28)$ & $04(16)$ & $05(20)$ & $01(04)$ & $02(08)$ & $25(100)$ \\
\hline S4 & $07(28)$ & $05(20)$ & $08(32)$ & $04(16)$ & $01(04)$ & $00(00)$ & $25(100)$ \\
\hline Total & $28(28)$ & $26(26)$ & $22(22)$ & $14(14)$ & $06(06)$ & $04(04)$ & $100(100)$ \\
\hline
\end{tabular}

Source: Field Survey Data, Note: Figures in Parentheses Indicates Percentages to their Total

\section{Occupational Status of Slum Dwellers}

The slum dwellers are mainly migrated from different places to urban India in search of getting some employment to earn money to meet their family expenditure and other living purpose. Table 9 reveals that $40 \%$ of total respondent slum dwellers' major occupation is daily labour. Out of these 40 samples, $32 \%$ are from S1 slum, $36 \%$ are from S2 slum, $48 \%$ are from S3 slum and $44 \%$ are from S4 slum area. It may be noticed that $16 \%$ of S1 slum area, $20 \%$ of S2, $24 \%$ of $\mathrm{S} 3$ and $28 \%$ of respondent slum dwellers from S4 slum are doing business for their livelihood. House construction is the major occupation for $20 \%$ of S1 slum, $16 \%$ of S2 slum, $8 \%$ of S3 slum and $12 \%$ of S4 slum. The street vending like sale of flowers, vegetable or vegetable leaf, fruits etc. is the main occupation for $12 \%$ in S1 slum, $8 \%$ each in S2 and S4 slums and $16 \%$ in S3 slum under reference. Doing job on temporary in Govt. organizations or in private sector is the major occupation for $12 \%$ of S1 slum dwellers, $8 \%$ of S2 slum dwellers and $4 \%$ each of S3 and S4 slum dwellers. Other activities such as welding work, painting, carpentry, tailoring etc. are the major occupations for $8 \%$ in $\mathrm{S} 1$ slum, $12 \%$ in $\mathrm{S} 2$ slum and $4 \%$ in $\mathrm{S} 4$ slum areas under study.

Table-9: Occupational Status of Respondent Slum Dwellers

\begin{tabular}{|c|c|c|c|c|c|c|c|}
\hline Slum & $\begin{array}{c}\text { Daily } \\
\text { Labour }\end{array}$ & Business & $\begin{array}{c}\text { House } \\
\text { Construction }\end{array}$ & $\begin{array}{c}\text { Street } \\
\text { Vending }\end{array}$ & Job & Other & Total \\
\hline S1 & $08(32)$ & $04(16)$ & $05(20)$ & $03(12)$ & $03(12)$ & $02(08)$ & $25(100)$ \\
\hline S2 & $09(36)$ & $05(20)$ & $04(16)$ & $02(08)$ & $02(08)$ & $03(12)$ & $25(100$ \\
\hline S3 & $12(48)$ & $06(24)$ & $02(08)$ & $04(16)$ & $01(04)$ & $00(00)$ & $25(100)$ \\
\hline S4 & $11(44)$ & $07(28)$ & $03(12)$ & $02(08)$ & $01(04)$ & $01(04)$ & $25(100)$ \\
\hline Total & $40(40)$ & $22(22)$ & $14(14)$ & $11(11)$ & $07(07)$ & $06(06)$ & $100(100)$ \\
\hline
\end{tabular}

Source: Field Survey Data, Note: Figures in Parentheses Indicates Percentages to their Total

\section{Origin of Slum Dwellers}

Generally the population living in slum areas is migrants from rural areas within the district or outside the district and from other states for their better livelihood, or for their children's education or to do some business in urban areas. As shown in table 10, $40 \%$ of respondent slum dwellers are migrated from rural areas of Ananthapuramu district and out of them 
$52 \%$ are located in $\mathrm{S} 1$ slum, $36 \%$ are staying in $\mathrm{S} 2$ slum, $32 \%$ in S3 and $40 \%$ are living in S4 slum under study. It may also noticed that $24 \%$ of S1 slum dwellers, $20 \%$ of S2 slum people, $36 \%$ of S3 slum and $16 \%$ of S4 slum dwellers are migrated from other districts and settled in the slums of Ananthapuramu town. It reveals that $12 \%$ in $\mathrm{S} 1$ slum, $32 \%$ in S2 slum and 24\% each in S3 and S4 slums were migrated to Ananthapuramu town from other states of India. They are mainly involving in house construction, carpentry, street vending etc. The remaining $13 \%$ of total selected slum dwellers are the residents of local slums and out of them majority of $20 \%$ are living in S4 slum under review.

\section{Reasons for Migration of Slum Dwellers}

Table-10: Origin of Migration of Respondent Slum Dwellers

\begin{tabular}{|c|c|c|c|c|c|}
\hline Slum & $\begin{array}{c}\text { Within } \\
\text { District }\end{array}$ & $\begin{array}{c}\text { Other } \\
\text { District }\end{array}$ & Other State & $\begin{array}{c}\text { Non } \\
\text { Migrant }\end{array}$ & Total \\
\hline S1 & $13(52)$ & $06(24)$ & $03(12)$ & $03(12)$ & $25(100)$ \\
\hline S2 & $09(36)$ & $05(20)$ & $08(32)$ & $03(12)$ & $25(100$ \\
\hline S3 & $08(32)$ & $09(36)$ & $06(24)$ & $02(08)$ & $25(100)$ \\
\hline S4 & $10(40)$ & $04(16)$ & $06(24)$ & $05(20)$ & $25(100)$ \\
\hline Total & $40(40)$ & $24(24)$ & $23(23)$ & $13913)$ & $100(100)$ \\
\hline
\end{tabular}

Source: Field Survey Data, Note: Figures in Parentheses Indicates Percentages to their Total

\section{Reasons for Migration to Slum Areas}

As shown in table $11,22 \%$ of slum dwellers were migrated from rural to urban areas, due to debt burden in their native places. $37 \%$ of slum dwellers were migrated in search of employment, $21 \%$ migrated for their children's education purpose, $16 \%$ of slum people migrated to do some business in urban area and remaining $4 \%$ of respondents were migrated for other reasons. It reveals that $20 \%$ in S1 slum, $16 \%$ in $\mathrm{S} 2$, $24 \%$ in S3 and $28 \%$ of slum dwellers in S4 were migrated to the slums to overcome their debt burdens at their native places. It may also observed that $48 \%$ in S1, $32 \%$ in $\mathrm{S} 2,36 \%$ in $\mathrm{S} 3$ and another $32 \%$ in S4 slum area were migrated for getting employment in urban town. For the purpose of children's education, $20 \%$ of dwellers in S1, $16 \%$ in S2 and 24\% each in S3 and S4 slum areas were migrated. For the reason of business, $12 \%$ each in S1 and S3, 24\% in S2 and $16 \%$ in S4 were migrated to urban area. $12 \%$ in S2 slum and only $4 \%$ in $\mathrm{S} 3$ slum were migrated to the slums for other reasons.

Table-11: Reasons for Migration to Slum Areas

\begin{tabular}{|c|c|c|c|c|c|c|}
\hline Slum & Debt Burden & Employment & $\begin{array}{c}\text { Children's } \\
\text { Education }\end{array}$ & Business & Other & Total \\
\hline S1 & $05(20)$ & $12(48)$ & $05(20)$ & $03(12)$ & $00(00)$ & $25(100)$ \\
\hline S2 & $04(16)$ & $08(32)$ & $04(16)$ & $06(24)$ & $03(12)$ & $25(100$ \\
\hline S3 & $06(24)$ & $09(36)$ & $06(24)$ & $03(12)$ & $01(04)$ & $25(100)$ \\
\hline S4 & $07(28)$ & $08(32)$ & $06(24)$ & $04(16)$ & $00(00)$ & $25(100)$ \\
\hline Total & $22(22)$ & $37(37)$ & $21(21)$ & $16(16)$ & $04(04)$ & $100(100)$ \\
\hline
\end{tabular}

Source: Field Survey Data, Note: Figures in Parentheses Indicates Percentages to their Total

\section{Type of Family of Slum Dwellers}

In many of the rural villages and urban areas, joint families are very low due to changes in the aptitude of the people. However, the present study reveals that $38 \%$ of the families in the slum areas are living with joint families. This may be mainly non- availability of shelter to the poor in urban slums. Table 12 shows that $68 \%$ in $\mathrm{S} 1$ slum, $56 \%$ in $\mathrm{S} 2$ slum, $64 \%$ in $\mathrm{S} 3$ slum and $60 \%$ in S4 slum have Nuclear families. On the other hand, $32 \%$ of slum dwellers in S1 slum, $44 \%$ in $\mathrm{S} 2$ slum, 36\% in $\mathrm{S} 3$ and $40 \%$ in $\mathrm{S} 4$ slum have joint families with more than 6 members in a house.

Table-12: Type of Family of Respondent Slum Dwellers

\begin{tabular}{|c|c|c|c|}
\hline Slum & Nuclear & Joint & Total \\
\hline S1 & $17(68)$ & $08(32)$ & $25(100)$ \\
\hline S2 & $14(56)$ & $11(44)$ & $25(100$ \\
\hline S3 & $16(64)$ & $09(36)$ & $25(100)$ \\
\hline S4 & $15(60)$ & $10(40)$ & $25(100)$ \\
\hline Total & $62(62)$ & $38(38)$ & $100(100)$ \\
\hline
\end{tabular}

Source: Field Survey Data, Note: Figures in Parentheses Indicates Percentages to their Total 


\section{Ownership of Dwelling of Slum Dwellers}

Out of the total respondent slum dwellers in the study area, 59\% are residing in owned houses, $38 \%$ are in rented houses and only $3 \%$ are residing in their friends or relatives houses on temporary shelter basis (Table 13). It reveals that $52 \%$ in $\mathrm{S} 1$ slum area, $56 \%$ in S2 slum area, $68 \%$ in S3 slum and $60 \%$ of slum dwellers in S4 slum area are residing in their own dwellings. On the other hand, $44 \%$ in $\mathrm{S} 1,36 \%$ of slum households in S2, 32\% in S3 and $40 \%$ of dwellers in S4 slum are staying in rented houses and one respondent in $\mathrm{S} 1$ and two respondents in S2 slum are living in their friends/relatives' houses.

Table-13: Ownership of Dwelling of Slum Dwellers

\begin{tabular}{|c|c|c|c|c|}
\hline Slum & Owned & Rented & Friends/Relatives & Total \\
\hline S1 & $13(52)$ & $11(44)$ & $01(04)$ & $25(100)$ \\
\hline S2 & $14(56)$ & $09(36)$ & $02(08)$ & $25(100$ \\
\hline S3 & $17(68)$ & $08(32)$ & $00(00)$ & $25(100)$ \\
\hline S4 & $15(60)$ & $10(40)$ & $00(00)$ & $25(100)$ \\
\hline Total & $59(59)$ & $38(38)$ & $03(03)$ & $100(100)$ \\
\hline
\end{tabular}

Source: Field Survey Data, Note: Figures in Parentheses Indicates Percentages to their Total

\section{Type of Dwellings of Slum Dwellers}

It reveals that $20 \%$ each in $\mathrm{S} 1$ and $\mathrm{S} 4$ slums, $16 \%$ in S3 slum and $24 \%$ of slum dwellers in S4 are living in RCC buildings with low square area (Table 14). The respondent slum dwellers residing in Pucca house are $20 \%$ each in S1 and S3 slums, $24 \%$ in S2 slum and $28 \%$ in S4 slum. $28 \%$ of slum people in S1 slum, 32\% in S2 slum, 24\% in S3 slum and 36\% in S4 slum are residing in Kuchcha houses with insecurity.
About $32 \%$ of slum dwellers each from S1 and S3 slums, $28 \%$ from S2 slum and $16 \%$ from S4 slum are living in Thatched house with very insecure and to be spoiled for rains and winds at any time. Out of 100 respondent slum dwellers, $20 \%$ of dwellers are residing in RCC building houses, $23 \%$ are living in Pucca houses, $30 \%$ are living in Kuchcha houses and the remaining $27 \%$ of respondent slum dwellers are living Thatched houses.

Table-14: Type of Dwelling Resided of Slum Dwellers

\begin{tabular}{|c|c|c|c|c|c|}
\hline Slum & RCC & Pucca & Kuchcha & Thatched & Total \\
\hline S1 & $05(20)$ & $05(20)$ & $07(28)$ & $08(32)$ & $25(100)$ \\
\hline S2 & $04(16)$ & $06(24)$ & $08(32)$ & $07(28)$ & $25(100$ \\
\hline S3 & $06(24)$ & $05(20)$ & $06(24)$ & $08(32)$ & $25(100)$ \\
\hline S4 & $05(20)$ & $07(28)$ & $09(36)$ & $04(16)$ & $25(100)$ \\
\hline Total & $20(20)$ & $23(23)$ & $30(30)$ & $27(27)$ & $100(100)$ \\
\hline
\end{tabular}

Source: Field Survey Data, Note: Figures in Parentheses Indicates Percentages to their Total

\section{Toilet cum Bath Room Facility Available in the Dwellings of Slum Dwellers}

It reveals that out of 100 sample respondent slum dwellers in four selected slums of Ananthapuramu town, only $46 \%$ of slum dwellers have toilet cum bath room facilities (Table 15). Some dwellers have bath rooms without toilet rooms. Even though the toilet room facilities are available, some are not utilizing the toilets and prefer for open defecation. $52 \%$ of dwellers in $\mathrm{S} 1$ slum, $44 \%$ in $\mathrm{S} 2$ slum, $48 \%$ in $\mathrm{S} 3$ slum and $40 \%$ in $\mathrm{S} 4$ slum have toilet cum bath room facilities. On the other hand, $54 \%$ of the total respondent slum dwellers have no toilet cum bath room facilities as majority of $57 \%$ are living in Kuchcha and Thatched houses. It is necessary to educate them for using toilets on one side and to provide toilet facility for each and every dwelling in slum areas to avoid open defecation.

Table-15: Toilet cum Bath Room Facility Available in the Dwelling of Respondent Slum Dwellers

\begin{tabular}{|c|c|c|c|}
\hline Slum & Yes & No & Total \\
\hline S1 & $13(52)$ & $12(48)$ & $25(100)$ \\
\hline S2 & $11(44)$ & $14(56)$ & $25(100$ \\
\hline S3 & $12(48)$ & $13(52)$ & $25(100)$ \\
\hline S4 & $10(40)$ & $15(60)$ & $25(100)$ \\
\hline Total & $46(46)$ & $54(54)$ & $100(100)$ \\
\hline
\end{tabular}

Source: Field Survey Data, Note: Figures in Parentheses Indicates Percentages to their Total

\section{Source of Drinking Water for Slum Dwellers}

Safe and ready available drinking water is important for public health, whether it is used for drinking, domestic use, food production or recreational purposes. Improved water supply and sanitation and better management of water resources can boost countries' economic growth and can contribute greatly to poverty reduction. In this context, every individual 
needs safe drinking water regularly. The data reveals that $58 \%$ of slum dwellers getting water from public taps in their slums, $26 \%$ of the respondent slum dwellers have Municipal tap connection for their dwellings and about $16 \%$ are purchasing mineral water for drinking purpose (Table 16). It may also noticed that $64 \%$ in $\mathrm{S} 1$ slum, $60 \%$ in S4 slum, $56 \%$ in $\mathrm{S} 2$ and $52 \%$ of slum dwellers in S3 slum area are getting water from public taps. $32 \%$ of dwellers in S2 slum, $28 \%$ in S3 slum, $24 \%$ in S4 slum and $20 \%$ in S1 slum have Municipal taps at their houses. $16 \%$ each in S1 and S4 slum, $20 \%$ in S3 slum, and $12 \%$ in S2 slum are purchasing mineral water for drinking purpose.

Table-16: Source of Drinking Water Available for Slum Dwellers

\begin{tabular}{|c|c|c|c|c|}
\hline Slum & Public Taps & $\begin{array}{c}\text { Municipal Tap } \\
\text { Connection }\end{array}$ & $\begin{array}{c}\text { Purchase of } \\
\text { Mineral Water }\end{array}$ & Total \\
\hline S1 & $16(64)$ & $05(20)$ & $04(16)$ & $25(100)$ \\
\hline S2 & $14(56)$ & $08(32)$ & $03(12)$ & $25(100$ \\
\hline S3 & $13(52)$ & $07(28)$ & $05(20)$ & $25(100)$ \\
\hline S4 & $15(60)$ & $06(24)$ & $04(16)$ & $25(100)$ \\
\hline Total & $58(58)$ & $26(26)$ & $16(16)$ & $100(100)$ \\
\hline
\end{tabular}

Source: Field Survey Data, Note: Figures in Parentheses Indicates Percentages to their Total

\section{Source of Entertainment and Reading News Papers for Slum Dwellers}

As shown in table 17, $44 \%$ of slum dwellers in $\mathrm{S} 1,40 \%$ in $\mathrm{S} 4$ slum, $36 \%$ in $\mathrm{S} 3$ and $32 \%$ in $\mathrm{S} 2$ slum have TV for entertainment of family members and to know daily news on various issues. Out of 100 sample slum dwellers, only 6 are getting entertainment and news by purchasing daily newspapers. It reveals that for $17 \%$ of respondent slum dwellers under study, Radio is the main entertainment. $12 \%$ in S1 slum, $20 \%$ each in $\mathrm{S} 2$ and $\mathrm{S} 4$ slum and $16 \%$ in $\mathrm{S} 3$ slum have radio facility in their dwellings for entertainment. For $32 \%$ of respondent slum dwellers in S3 slum, $28 \%$ of dwellers in S1 slum, 24\% each in S2 and S4 slums are using mobile phones for entertainment and to get the daily news. Out of 100 sample households in the study area, $12 \%$ of slum dwellers have no facilities for entertainment and for news and they are depending on others.

Table-17: Source of Entertainment and News for Respondent Slum Dwellers

\begin{tabular}{|c|c|c|c|c|c|c|}
\hline Slum & TV & News Papers & Radio & $\begin{array}{c}\text { Mobile } \\
\text { Phones }\end{array}$ & $\begin{array}{c}\text { Hear from } \\
\text { Others }\end{array}$ & Total \\
\hline S1 & $11(44)$ & $00(00)$ & $03(12)$ & $07(28)$ & $04(16)$ & $25(100)$ \\
\hline S2 & $08(32)$ & $03(12)$ & $05(20)$ & $06(24)$ & $03(12)$ & $25(100$ \\
\hline S3 & $09(36)$ & $02(08)$ & $04(16)$ & $08(32)$ & $02(08)$ & $25(100)$ \\
\hline S4 & $10(40)$ & $01(04)$ & $05(20)$ & $06(24)$ & $03(12)$ & $25(100)$ \\
\hline Total & $38(38)$ & $06(06)$ & $17(17)$ & $27(27)$ & $12(12)$ & $100(100)$ \\
\hline
\end{tabular}

Source: Field Survey Data, Note: Figures in Parentheses Indicates Percentages to their Total

\section{Number of Adult Family Members in Respondent's Dwellings}

As shown ion table $18,11 \%$ of total respondent house hold families have less than 2 members in the family with $12 \%$ each in S1, S2 and S3 slum areas and $8 \%$ of households in S3 slum area. It may also noticed that $12 \%$ of slum dwellers each in $\mathrm{S} 1$ and S4 slums and $8 \%$ of slum dwellers each in S2 and S3 slums have 2-3 family members in the house. It reveals that there are $3-5$ family members in $32 \%$ of the families of S1 and S2 slums, in $36 \%$ of families in S3 slum and in $28 \%$ of the families in S4 slum under study. There are 5-6 members in a family in $28 \%$ of the families of S2 slum, $20 \%$ of the families each in S1 and $\mathrm{S} 2$ slums and $24 \%$ of the families in S4 slum area. It may also noticed that above 6 members are there in a family in $24 \%$ of the families each of S1 and S4 slums, in $28 \%$ of the families in S2 slum and $20 \%$ of the houses in S3 slum area under review.

Table-18: Number of Family Members of Respondent Slum Dwellers ( in Numbers)

\begin{tabular}{|c|c|c|c|c|c|c|}
\hline Slum & $<\mathbf{2}$ & $\mathbf{2 - 3}$ & $\mathbf{3 - 5}$ & $\mathbf{5 - 6}$ & $\mathbf{> 6}$ & Total \\
\hline S1 & $03(12)$ & $03(12)$ & $08(32)$ & $05(20)$ & $06(24)$ & $25(100)$ \\
\hline S2 & $03(12)$ & $02(08)$ & $08(32)$ & $05(20)$ & $07(28)$ & $25(100$ \\
\hline S3 & $02(08)$ & $02(08)$ & $09(36)$ & $07(28)$ & $05(20)$ & $25(100)$ \\
\hline S4 & $03(12)$ & $03(12)$ & $07(28)$ & $06(24)$ & $06(24)$ & $25(100)$ \\
\hline Total & $11(11)$ & $10(10)$ & $32(32)$ & $23(23)$ & $24(24)$ & $100(100)$ \\
\hline
\end{tabular}

Source: Field Survey Data, Note: Figures in Parentheses Indicates Percentages to their Total 


\section{Household Furniture/Assets of Slum Dwellers}

The standard of life and the living conditions of the households can assess on the basis of availability of household furniture and other assets with them. TV is one of the essential entertainment item for rich and poor or for small and big families. Out of total respondent slum dweller households, only $38 \%$ are using TVs in their dwellings (Table 19). It may be observed that $44 \%$ of slum dwellers in S1 slum, $40 \%$ of S4 slum area, $36 \%$ of S3 slum and $32 \%$ of dwellers in S2 slum area have
TV facility. Only $12 \%$ out of 100 sample respondent dwellers have Fridge facility in their dwellings. 21\% out of total selected dweller households have chairs and fans in their houses. A majority of $94 \%$ of total respondent households has a facility of mobile phones and in some dwellings they have more than one mobile phones which are essential for now days for all sections of society. They are using mobiles for entertainment purpose also.

Table-19: Household Furniture/Assets of Respondent Slum Dwellers

\begin{tabular}{|c|c|c|c|c|c|c|}
\hline Slum & TV & Fridge & $\begin{array}{c}\text { Fans \& } \\
\text { Chairs }\end{array}$ & $\begin{array}{c}\text { Mobile } \\
\text { Phones }\end{array}$ & $\begin{array}{c}\text { Two } \\
\text { Wheelers }\end{array}$ & Auto \\
\hline S1 & $11(44)$ & $03(12)$ & $04(16)$ & $25(100)$ & $10(40)$ & $03(12)$ \\
\hline S2 & $08(32)$ & $04(16)$ & $06(24)$ & $22(88)$ & $13(52)$ & $04(16)$ \\
\hline S3 & $09(36)$ & $03(12)$ & $05(20)$ & $24(96)$ & $14(56)$ & $06(36)$ \\
\hline S4 & $10(40)$ & $02(08)$ & $06(24)$ & $23(92)$ & $11(44)$ & $05(20)$ \\
\hline Total & $38(38)$ & $12(12)$ & $21(21)$ & $94(94)$ & $45(45)$ & $18(18)$ \\
\hline
\end{tabular}

Source: Field Survey Data, Note: Figures in Parentheses Indicates Percentages to their Total

All the sample dwellers in S1 slum, $24 \%$ of dwellers in S3 slum, $23 \%$ in S4 slum and $22 \%$ of dwellers in S2 slum area have mobile phone facility. About $45 \%$ of total slum dweller households have two wheelers as they are using it as a transport for attending their daily wage employment and for other purpose. $56 \%$ of dwellers in S3 slum, $52 \%$ in S2 slum, $44 \%$ in $\mathrm{S} 4$ slum and $40 \%$ in S1 slum area are using two wheelers. Auto is availing by $18 \%$ of the families with $36 \%$ in S3 slum, $20 \%$ in S4 slum, $16 \%$ in S2 slum and $12 \%$ of dwellers in S1 slum areas. They are earning money through Auto transport and for some families it is the major source of income.

\section{Energy for Cooking Purpose}

It reveals that $54 \%$ of total respondent slum dwellers are using firewood as a major fuel for cooking. $60 \%$ of dwellers in S3 slum, $56 \%$ in S2 slum, $52 \%$ in $\mathrm{S} 1$ slum and $48 \%$ in $\mathrm{S} 4$ slum are using fire wood as a fuel for cooking (table 20). About $40 \%$ of dwellers in S4 slum, $36 \%$ in S2 slum, and $32 \%$ of slum dwellers each in S1 and S3 slum areas are using Gas stoves for cooking purpose. Only $11 \%$ of total dwellers are using electrical stoves for cooking under study. It shows that $16 \%$ of slum dwellers in S1 slum and $8 \%$ of households in all the remaining slums are using electrical stoves.

Table-20: Energy Use for Cooking Purpose

\begin{tabular}{|c|c|c|c|c|}
\hline Slum & Fire Wood & Gas Stove & $\begin{array}{c}\text { Electrical } \\
\text { Stoves }\end{array}$ & Total \\
\hline S1 & $13(52)$ & $08(32)$ & $04(16)$ & $25(100)$ \\
\hline S2 & $14(56)$ & $09(36)$ & $02(08)$ & $25(100$ \\
\hline S3 & $15(60)$ & $08(32)$ & $02(08)$ & $25(100)$ \\
\hline S4 & $12(48)$ & $10(40)$ & $03(12)$ & $25(100)$ \\
\hline Total & $54(54)$ & $35(35)$ & $11(11)$ & $100(100)$ \\
\hline
\end{tabular}

Source: Field Survey Data, Note: Figures in Parentheses Indicates Percentages to their Total

\section{Income Levels of Slum Dwellers}

The annual income of the slum dweller households depends on number of working adults in the family and availability of regular employment opportunities to them. Generally, the slum people are working in private sector at low wage rates and because of this reason, the income levels are also poor comparatively other urban population. The income levels of sample dwellers living in slum areas are categorized into four i.e., below Rs. 60,000, Rs.60,001 to Rs. $1,00,000$, Rs. $1,00,001$ to Rs.2,00,000 and above Rs. $2,00,000$. It is observed that $20 \%$ of slum dwellers in $\mathrm{S} 1$ slum, $24 \%$ in $\mathrm{S} 2$ slum, $16 \%$ in $\mathrm{S} 3$ slum and $28 \%$ in S4 slum are in the income group of less than Rs. $60,000.36 \%$ of dwellers in S3 slum, $32 \%$ of dwellers in $\mathrm{S} 1$ slum, $28 \%$ in $\mathrm{S} 2$ and $16 \%$ of respondent slum dwellers in S4 are in the income group of Rs.60, 001 to Rs.1,00,000. It may be noticed that $40 \%$ in S4 slum, $36 \%$ in $\mathrm{S} 2$ slum, $32 \%$ in $\mathrm{S} 3$ slum and $28 \%$ in $\mathrm{S} 1$ slum are in the income group of Rs.1,00,001 to Rs. Rs.2,00,000. $16 \%$ of households each in S3 and S4 slums, $20 \%$ in S1 slum and $12 \%$ in S2 slum are in the income group of above Rs.2,00,000. 
Table-21: Annual Income of Respondent Slum Dwellers (in Rupees)

\begin{tabular}{|c|c|c|c|c|c|}
\hline Slum & $<\mathbf{6 0 , 0 0 0}$ & $\mathbf{6 0 , 0 0 1 - 1 , 0 0 , 0 0 0}$ & $\mathbf{1 , 0 0 , 0 0 1 - 2 , 0 0 , 0 0 0}$ & $\mathbf{> 2 , 0 0 , 0 0 0}$ & Total \\
\hline S1 & $05(20)$ & $08(32)$ & $07(28)$ & $05(20)$ & $25(100)$ \\
\hline S2 & $06(24)$ & $07(28)$ & $09(36)$ & $03(12)$ & $25(100$ \\
\hline S3 & $04(16)$ & $09(36)$ & $08(32)$ & $04(16)$ & $25(100)$ \\
\hline S4 & $07(28)$ & $04(16)$ & $10(40)$ & $04(16)$ & $25(100)$ \\
\hline Total & $22(22)$ & $28(28)$ & $34(34)$ & $16(16)$ & $100(100)$ \\
\hline
\end{tabular}

Source: Field Survey Data, Note: Figures in Parentheses Indicates Percentages to their Total

\section{Expenditure Pattern of Slum Dwellers}

The expenditure on food consumption, and other daily needs, social functions, children's education and medical expenditure are common in all families. Based on the income levels of individuals they can spend the amount on various items. $14 \%$ of total respondent slum dwellers are spending less than Rs. 60,000 per annum from their sources of income. $40 \%$ of the total sample households in the slum areas are spending Rs.60, 001 to Rs.1, 00,000 per annum. 29\% of sample dwellers under study are spending Rs.1,00,001 to Rs.2,00,000 per annum. About $16 \%$ of the dwellers are spending above Rs.2,00,000 per annum. It may also observed that $20 \%$ of households in S1, 24\% in S2 slum, $16 \%$ in S3 slum and $28 \%$ in S4 slum are meeting an amount of less than Rs. 60,000 for their family expenditure. $36 \%$ in S3, 32\% in S1, $28 \%$ in $\mathrm{S} 2$ and $16 \%$ in S4 slum are spending Rs.60,001 to Rs.1,00,000 for family needs. $40 \%$ in S4 slum, $36 \%$ in S2, $32 \%$ in S3, and $28 \%$ in S1 slum are spending Rs.1,00,001 to Rs.2,00,000 for their family expenditure. $16 \%$ each from S3 and S4 slums, 12\% from S2 slum and 20\% from $\mathrm{S} 1$ slum are spending an amount of more than Rs. $2,00,000$ per annum to meet their family expenditure.

Table-22: Annual Expenditure of Respondent Slum Dwellers (in Rupees)

\begin{tabular}{|c|c|c|c|c|c|}
\hline Slum & $<\mathbf{6 0 , 0 0 0}$ & $\begin{array}{c}\mathbf{6 0 , 0 0 0 -} \\
\mathbf{1 , 0 0 , 0 0 0}\end{array}$ & $\begin{array}{c}\mathbf{1 , 0 0 , 0 0 1 -} \\
\mathbf{2 , 0 0 , 0 0 0}\end{array}$ & $\mathbf{> 2 , 0 0 , 0 0 0}$ & Total \\
\hline S1 & $03(12)$ & $12(48)$ & $07(28)$ & $03(12)$ & $25(100)$ \\
\hline S2 & $04(16)$ & $10(40)$ & $06(24)$ & $05(20)$ & $25(100$ \\
\hline S3 & $02(08)$ & $09(36)$ & $10(40)$ & $04(16)$ & $25(100)$ \\
\hline S4 & $05(20)$ & $09(36)$ & $06(24)$ & $05(20)$ & $25(100)$ \\
\hline Total & $14(14)$ & $40(40)$ & $29(29)$ & $17(17)$ & $100(100)$ \\
\hline
\end{tabular}

Source: Field Survey Data, Note: Figures in Parentheses Indicates Percentages to their Total

\section{Level of Savings of Slum Dwellers}

It reveals that $36 \%$ of dwellers in $\mathrm{S} 1$ slum, $32 \%$ each in S2 and S4 slums and $28 \%$ in S3 slum are managing savings upto Rs. 10,000 per annum. $40 \%$ of dwellers from each $\mathrm{S} 1$ and S4 slum, $36 \%$ in $\mathrm{S} 2$ slum and $32 \%$ in S3 slum are managing savings of Rs.10,001 to Rs. 20,000 per annum. $20 \%$ of sample dwellers each in $\mathrm{S} 1$ and $\mathrm{S} 4$ slums, $16 \%$ in $\mathrm{S} 3$ slum and $24 \%$ in $\mathrm{S} 2$ slum are maintaining savings of Rs.20,001 to Rs. 30,000 . Only $4 \%$ of dwellers in S1 slum, $8 \%$ each in S2 and S4 slums and $24 \%$ in S3 slims are generating savings of above Rs.30,000 per annum.

Table-23: Annual Savings of Respondent Slum Dwellers (in Rupees)

\begin{tabular}{|c|c|c|c|c|c|}
\hline Slum & $<\mathbf{1 0 , 0 0 0}$ & $\mathbf{1 0 , 0 0 1 - 2 0 , 0 0 0}$ & $\mathbf{2 0 , 0 0 1 - 3 0 , 0 0 0}$ & $\mathbf{> 3 0 , 0 0 0}$ & Total \\
\hline S1 & $09(36)$ & $10(40)$ & $05(20)$ & $01(04)$ & $25(100)$ \\
\hline S2 & $08(32)$ & $09(36)$ & $06(24)$ & $02(08)$ & $25(100$ \\
\hline S3 & $07(28)$ & $08(32)$ & $04(16)$ & $06(24)$ & $25(100)$ \\
\hline S4 & $08(32)$ & $10(40)$ & $05(20)$ & $02(08)$ & $25(100)$ \\
\hline Total & $32(32)$ & $37(37)$ & $20(20)$ & $11(11)$ & $100(100)$ \\
\hline
\end{tabular}

Source: Field Survey Data, Note: Figures in Parentheses Indicates Percentages to their Total

\section{SUMMARY}

Increased population caused for the subdivision of land holdings and resulted small land holdings which are not remunerative for farmers as well as agricultural labourers. This resulted for rural to urban migration. For the increased urban population lands are not adequate to construct the houses. With the low income of migrant labour occupying government lands and constructing temporary shelters at low cost and caused for growth of slums. The living conditions of slum dwellers are poor with their inadequate income and employment. The housing conditions of slum dwellers are poor. The job opportunities are low and are engaging in low wage jobs on daily wage base. The educational standards are poor and are not concentrating on their children's education. Some are sending their children for wage employment at their child age. Due to poor sanitary and unhygienic conditions, the health status among the slum dwellers is also poor. 
It is necessary to provide proper infrastructural facilities in the slum areas. Internal roads, drainage system to be improved. Creating awareness on maintaining health and avoiding alcohol and tobacco consumption among slum dwellers is necessary. Government should create or provide self-employment opportunities for needy slum dwellers. The educational facilities to be improved. Gas stoves to be provided to all slum dwellers to avoid fire wood for cooking purpose. Safe drinking water facility to all dwellings to be provided at free of cost by local bodies.

\section{REFERENCES}

1. Oni AA. Globalization and Its Implication on African Culture and Development: Challenges for Education. International Journal of African \& African-American Studies. 2009 Mar 26;4(2).

2. Naveed M, Anwar M. Socio-Economic Condition and Health Status of Urban Slums: A Case Study of
Jogo Chak, Sialkot. Asian Journal of Social Sciences and Humanities. 2014 Nov;3(4).

3. Goswami S, Manna S. Urban poor living in slums: a case study of Raipur city in India. Global Journal of Human Social Science Sociology \& Culture. 2013;13(4):15-22.

4. Al-Samarrai S, Peasgood T. Educational attainments and household characteristics in Tanzania. Economics of education review. 1998 Oct 1;17(4):395-417.

5. Akter MS, Upal M, Hani U. Service quality perception and satisfaction: a study over sub-urban public hospitals in Bangladesh. Journal of Services Research. 2008 Feb 1:125.

6. Nangia S and Thorat S. Slum in Metropolis, Delhi, Shipra Publications, Delhi; 2000.

7. Madhusoodhanan V. Rehabilitation Measures for Slum Dwellers in Thiruvananthapuram City, in Ed. Nair, KN and Gopikuttan G, Housing in Kerala, Daanish Books, New Delhi;2006. 